\title{
Primary Production in a Subtropical Stratified Coastal Lagoon-Contribution of Anoxygenic Phototrophic Bacteria
}

\author{
Maria Luiza S. Fontes • Marcelino T. Suzuki • \\ Matthew T. Cottrell • Paulo C. Abreu
}

Received: 18 April 2010 / Accepted: 8 August 2010/Published online: 1 September 2010

(C) Springer Science+Business Media, LLC 2010

\begin{abstract}
Anaerobic anoxygenic phototrophic bacteria can be found in the suboxic waters of shallow stratified coastal systems, and may play important roles in the total primary production of subtropical stratified coastal lagoons. We investigated the spatiotemporal variability of light $\mathrm{CO}_{2}$ fixation and net oxygen production in the stratified Con-
\end{abstract}

\author{
M. L. S. Fontes $\cdot$ P. C. Abreu \\ Institute of Oceanography, Federal University of Rio Grande, \\ Av. Itália km 8, Campus Carreiros, \\ Rio Grande, Rio Grande do Sul, Brazil \\ M. T. Suzuki \\ Chesapeake Biological Laboratory, \\ University of Maryland Center for Environmental Science, \\ One Williams St, P.O. Box 38, Solomons, MD 20688, USA \\ M. T. Cottrell \\ College of Earth, Ocean, and Environment, \\ University of Delaware, \\ 700 Pilottown Rd, \\ Lewes, DE 19958, USA \\ M. T. Suzuki \\ CNRS, UMR 7621, LOMIC, Observatoire Océanologique, \\ F-66651 Banyuls/mer, France
}

Present Address:

M. L. S. Fontes $(\square)$

Laboratório de Bioquímica e Biologia Molecular de

Microorganismos, Departamento de Ecologia e Zoologia,

Universidade Federal de Santa Catarina,

Campus Trindade,

Florianópolis, Santa Catarina, Brazil

e-mail: fontesml@ccb.ufsc.br

Present Address:

M. T. Suzuki

UPMC Univ Paris 06, UMR 7621, LOMIC,

Observatoire Océanologique,

F-66650 Banyuls/mer, France ceição Lagoon (Brazil) in summer and fall of 2007, as well as the contribution of bacteriochlorophyll $a$ (BChl $a$ )containing bacteria to photosynthetically driven electron transfer. Both chlorophyll $a$ ( $\mathrm{Chl} a$ ) and BChl $a$ varied in space, while only $\mathrm{BChl} a$ varied in time (three-fold increase from summer to fall). In summer, net oxygen production and light $\mathrm{CO}_{2}$ fixation were correlated, with both having higher rates with higher $\mathrm{Chl} a$ concentrations in the enclosed region of the lagoon. In fall, $\mathrm{CO}_{2}$ fixation was decoupled from oxygen production. Denaturing gradient gel electrophoresis revealed that bacterial communities of oxic site 12 and suboxic site 33 formed one cluster, different from other oxic samples within the lagoon. In addition, $\mathrm{BChl} a / \mathrm{Chl} a$ ratios at these sites were high, $40 \%$ and $45 \%$, respectively. Light acted as the main factor controlling the $\mathrm{BChl} a$ concentration and $\mathrm{CO}_{2}$ fixation rates. High turbidity within the enclosed area of the lagoon explained high $\mathrm{BChl} a$ and decoupling between $\mathrm{CO}_{2}$ fixation and oxygen production in oxygenated waters. Contribution of purple sulfur bacteria to total bacterial density in suboxic waters was $1.2 \%$, and their biomass contributed to a much higher percentage (12.2\%) due to their large biovolume. Our results indicate a significant contribution of anaerobic anoxygenic bacteria to the primary production of the "dead zone" of Conceição Lagoon.

\section{Introduction}

Coastal ecosystems (lagoons and estuaries) are among the most productive aquatic systems, exporting fixed carbon, nitrogen, and phosphorus to adjacent oligotrophic oceans [45]. Primary production (PP) in these ecosystems is very dynamic, being strongly affected by physicochemical processes, such as freshwater nutrient runoff and re-suspension. Therefore, concurrent physicochemical characterization of the water 
column is usually performed to study these dynamic systems (i.e., $[1,2,40])$. Primary production in estuaries and lagoons at subtropical latitudes throughout the world range from as high as $7.28 \mathrm{~g} \mathrm{C} \mathrm{m}^{-2}$ day $^{-1}$ in Chiku Lagoon, Taiwan [38] to $0.34 \mathrm{~g} \mathrm{C} \mathrm{m}^{-2}$ day $^{-1}$ at Estero de Punta Banda, Mexico [41], typical of eutrophic estuaries. These high rates of PP in coastal waters usually promote the accumulation of particulate organic matter at their bottom, with heterotrophic activity depleting oxygen if it is not supplied by advective processes or vertical mixing and creating so-called dead zones. These are regions where fish, crustaceans, and benthic organisms are excluded due to oxygen levels $<2$ to $3 \mathrm{mg} \mathrm{L}^{-1}[5,13,59]$. More than 400 systems throughout the world have already reported such dead zones, including Conceição Lagoon in Southern Brazil, where half of these zones occur seasonally [14].

In addition, increasing ocean temperatures and fossil fuel burning are the major causes of expanding dead zones worldwide, and the combined effect of decreasing oxygen and increasing ocean $\mathrm{CO}_{2}$ can be severe [6]. In shallow coastal aquatic systems where light can reach the dead zones, the rise in the $\mathrm{CO}_{2}$ concentration might, in turn, favor a specialized group of prokaryotic primary producer, anaerobic anoxygenic phototrophic (AnAnP) bacteria.

As it has been observed worldwide, bottom hypoxia in Conceição Lagoon develops due to two factors: stratification of the water column and high primary production in surface waters [47, 52]. Anoxia has been reported in the central sector of the system since 1982 [47], when the permanent opening of a channel that connects the lagoon to the open ocean occurred. Before that, water was completely mixed [3]. These anoxic waters have also shown the highest concentrations of photosynthetic biomass, e.g., $1,604 \mu \mathrm{g} \mathrm{L}^{-1}$ of chlorophyll a (Chl $a$ ) was found in May of 1984 [47] and $32.5 \mu \mathrm{g} \mathrm{L}{ }^{-1}$ of Chl $a$ in March of 2003, which was observed under an $\mathrm{H}_{2} \mathrm{~S}$ concentration of $34 \mu \mathrm{mol} \mathrm{L} \mathrm{L}^{-1}$ and with water discoloration (pinkish waters) [19], while Chl $a$ averages 4 to $5 \mu \mathrm{g} \mathrm{L}^{-1}$ in the lagoon.

Finding measurable/high sulfide concentrations concomitantly with pinkish waters indicates the presence of purple sulfur bacterium (PSB), order Chromatiales, an AnAnP bacteria. Anoxygenic phototrophic bacteria contain the photosynthetic pigment called bacteriochlorophyll a (BChl a) instead of $\mathrm{Chl} a$, found in oxygenic phototrophs and have also been called BChla-containing bacteria. These bacteria can be classified into two groups: anaerobic and aerobic. A significant difference between aerobic and anaerobic is that the aerobic anoxygenic phototrophic bacteria (AAnP) cannot fix $\mathrm{CO}_{2}$ autotrophically. The occurrence of AnAnP bacteria (the anaerobic ones!) in Conceição Lagoon was first suggested by Odebrecht and Caruso [47], but their role in the total primary production has never been studied.

In other stratified lakes and lagoons, AnAnP bacteria may account for high primary production rates, for instance, up to $47 \%$ at Lake Estanya and $52 \%$ at Lake Cisó [8] and up to $10 \%$ at the oxic/anoxic interface of the Ebro River estuary [9]. Therefore, it is expected that AnAnP bacteria contribute substantially to the primary production in the suboxic waters in Conceição Lagoon. Fontes and Abreu [20] suggested the light intensity and the stratification index as the main regulators of the structure of the prokaryotic community in bottom waters and that bacterial abundance at the bottom was higher than in surface waters. Consequently, AnAnP bacteria might be present in the suboxic waters and play a significant role in total primary production of Conceição Lagoon.

Regarding the role of microorganisms in Conceição Lagoon, the aims of this study were to investigate the following: (a) the spatiotemporal variability of oxygen production/consumption and total primary production and (b) the contribution of AnAnP bacteria to total photosynthesis.

\section{Experimental Procedures}

\section{Study Site}

Conceição Lagoon is a shallow, choked coastal lagoon [30] located at Florianópolis island in southern Brazil (Fig. 1). The lagoon is connected to the South Atlantic Ocean by one long meandering channel, Canal da Barra, which has a significant role in the lagoon's water renewal processes [17]. It has an area of approximately $20 \mathrm{~km}^{2}$, with a total watershed area of $80.23 \mathrm{~km}^{2}$ (E. Porto-Filho, unpublished data). The mean and maximum depths are 1.7 and $8.7 \mathrm{~m}$, respectively [42]. Light frequently reaches the bottom of the entire lagoon, and river inputs are of minor importance, with precipitation and groundwater acting as major freshwater sources [18]. Morphological features and differences in physical and chemical characteristics of the water body have led to the division of Conceição Lagoon into different sectors since the first ecological study in this ecosystem [31].

\section{Sampling Strategy and Abiotic Parameters}

Water samples were collected from south, central, and north sectors of Conceição Lagoon (Fig. 1) in two different seasons (Austral summer-January/February 2007; Austral fall-April/May 2007) to compare primary production under different trophic and environmental conditions. Water samples were collected with a 3-L van Dorn bottle from two depths, $0.5 \mathrm{~m}$ below surface (surface water) and $0.5 \mathrm{~m}$ above the sediment (bottom water), transferred into acidcleaned 1.5-L polypropylene bottles (for pigment and nutrient analyses) and then into BOD bottles (for in situ primary production incubations). 
Figure 1 Conceição Lagoon location and stations sampled in the lagoon during January/February (summer) and April/May (fall) of 2007

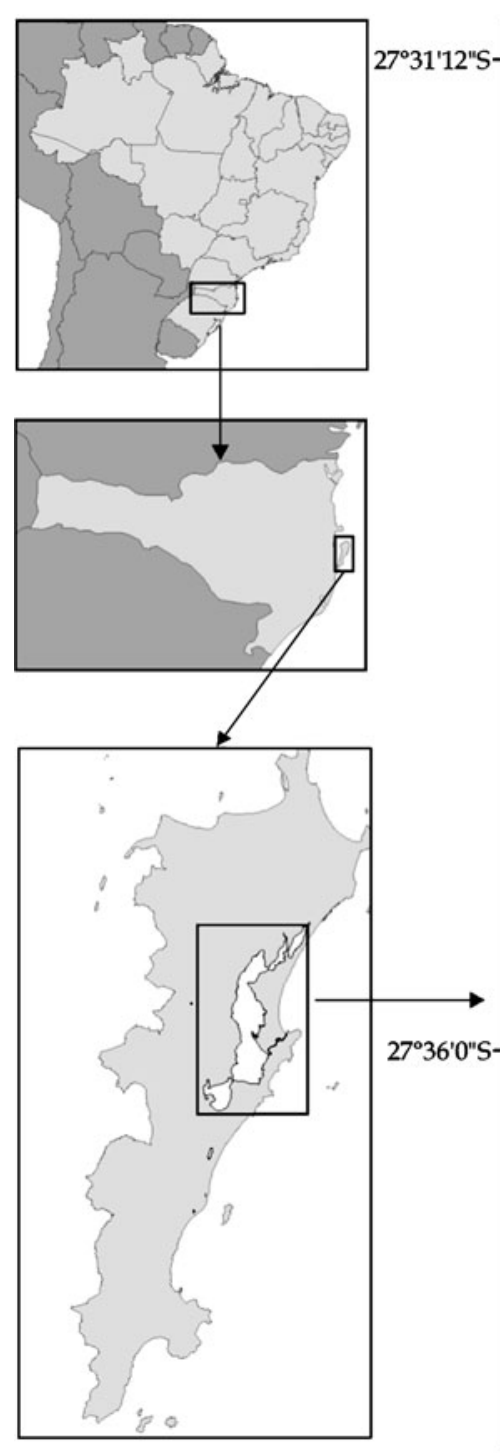

6

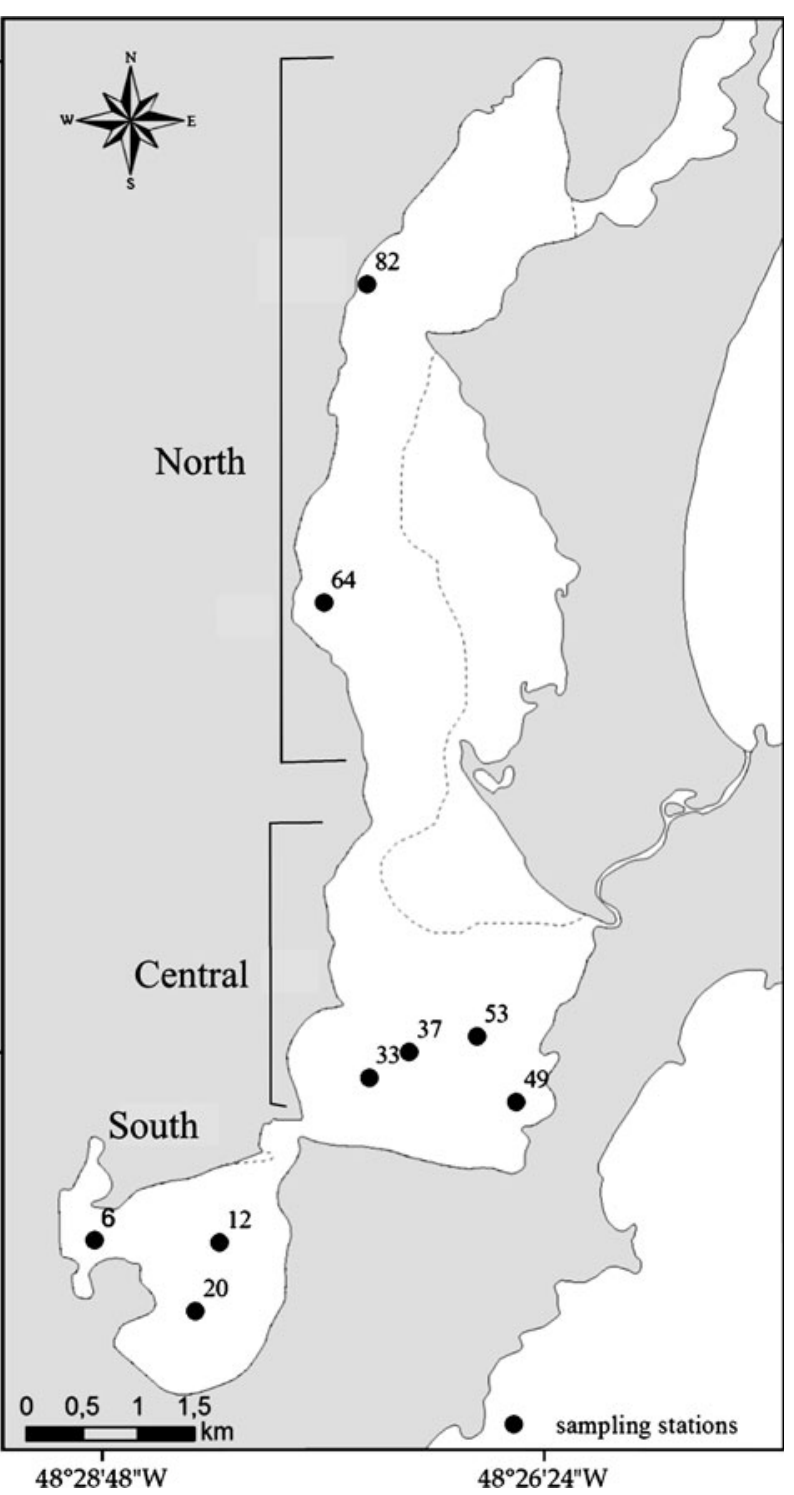

Temperature, dissolved oxygen, and salinity were measured in situ with a calibrated multi-parameter sensor DO 85 (YSI, Yellow Springs, OH, USA). Oxygen concentrations $<0.72 \mathrm{mg} \mathrm{L}^{-1}$ (or $<0.5 \mathrm{~mL} \mathrm{~L}^{-1}$ ) were considered suboxic $[14,26]$, and $3 \mathrm{mg} \mathrm{L}^{-1}$ was considered the limit between hypoxic and oxic waters $[5,12]$ because this was the same hypoxic threshold used in a previous study [20]. Measurements of alkalinity were also conducted, and the concentration of total $\mathrm{CO}_{2}$ was estimated using algorithms including alkalinity, salinity, temperature, and $\mathrm{pH}$ of the samples [53] measured with a DMPH-3 pH-meter (Digimed, São Paulo, Brazil). The stratification index was determined as the absolute value of the difference between the bottom and surface water salinities. Secchi disk depth (SEC) was used to estimate the irradiance attenuation coefficient, $k$, and photosynthetically active radiation (PAR) was calculated from the incident light, $I_{0}$, at the surface water (see Fontes and Abreu [20] for details).

Photosynthetic Pigments and Inorganic Nutrients

Approximately $500-\mathrm{mL}$ water aliquots were filtered through GF/F filters (Whatman, Maidstone, UK; 0.7- $\mu$ m nominal pore size) immediately after collection to determine $\mathrm{Chl} a, \mathrm{BChl} a$, and inorganic nutrients (ammonium, nitrate plus nitrite, and phosphate). GF/F filters and the filtrate were stored at $-20^{\circ} \mathrm{C}$ prior to analysis. Inorganic nutrients were analyzed according to Grasshoff et al. [23]. Chl $a$ (of oxygenic phototrophs) and $\mathrm{BChl} a$ (of anoxygenic phototrophs) were extracted from the $\mathrm{GF} / \mathrm{F}$ filters with $90 \%$ acetone for $24 \mathrm{~h}$ at $4^{\circ} \mathrm{C}$ in the dark. Pigment concentrations of the organic extracts were estimated from the absorbance at 665 and $730 \mathrm{~nm}$ (turbidity correction) 
for Chl $a$ and at 772 and $880 \mathrm{~nm}$ (turbidity correction) for BChl $a$ using a model $600 \mathrm{~S}$ spectrophotometer (FEMTO, São Paulo, Brazil) [29, 53]. Assuming that the rates of photosynthesis scale with the concentrations of photosynthetic pigments, the BChl $a$-to-Chl $a^{-1}$ ratio $\left(\mathrm{mol} \times \mathrm{mol}^{-1}\right)$ was used to estimate the contribution of $\mathrm{BChl} a$-containing bacteria to photosynthetically driven electron transport $[22,36]$.

\section{Primary Production Measurements}

Two methods were applied to evaluate the net oxygen production $\left(\mathrm{O}_{2}\right.$ method) and inorganic carbon fixation $\left(\mathrm{H}^{14} \mathrm{CO}_{3}{ }^{-}\right.$method) in conjunction with the biological oxygen demand (BOD), which allowed the estimation of community respiration (CR) rates. Water aliquots were carefully transferred to borosilicate glass BOD bottles and allowed to overflow three times of their volumes to avoid air contamination. Three hundred-milliliter BOD bottles were used for oxygen production (two light and two dark), and 120$\mathrm{mL}$ BOD bottles were used for ${ }^{14} \mathrm{C}$-fixation (two light and two dark) incubations. For ${ }^{14} \mathrm{C}$-fixation experiments, each BOD bottle was first spiked with $1 \mathrm{~mL}$ of oxygen-free $\mathrm{NaH}^{14} \mathrm{CO}_{3}(5 \mu \mathrm{Ci})$. Before incubation, triplicate subsamples were taken from the oxygen bottles to quantify the initial dissolved oxygen concentration, and six $50-\mu \mathrm{L}$ subsamples were transferred to $20-\mathrm{mL}$ glass scintillation vials and fixed with $2 \%$ formaldehyde (final concentration) to determine initial ${ }^{14} \mathrm{C}$ levels. Incubations were carried out immediately in situ at the same depth as samples were collected for $4 \mathrm{~h}$ (generally between 0830 and 1230 hours local time). At the end of the incubation period, all oxygen BOD bottles were immediately analyzed with the oxygen probe on board. Net oxygen production (OP) was estimated as the production of oxygen in the light, and planktonic community respiration was estimated as the oxygen consumption in the dark. Duplicate 8-mL subsamples were taken from each ${ }^{14} \mathrm{C}$ bottle, transferred to glass scintillation vials, and spiked with $0.4 \mathrm{~mL}$ of $37 \%$ formaldehyde to kill existing cells. In the laboratory, these subsamples were acidified with $1 \mathrm{~mL}$ of $6 \mathrm{~N}$ $\mathrm{HCl}$, bubbled with air for $20 \mathrm{~min}$ to eliminate unincorporated ${ }^{14} \mathrm{CO}_{2}$, and neutralized with $1 \mathrm{~mL}$ of $6 \mathrm{~N} \mathrm{NaOH}$. The volume was brought up to $20 \mathrm{~mL}$ with a scintillation cocktail [44,51]. Radioactivity in the samples was counted in an LS 6500 model (Beckman Coulter, Fullerton, CA, USA) liquid scintillation counter.

Light inorganic carbon fixation is carried out by both oxygenic and anaerobic anoxygenic photosynthetic bacteria (AnAnP). The estimation of light $\mathrm{CO}_{2}$ fixation $\left(\mathrm{CO}_{2}\right.$ fixation) rates was calculated from the inorganic carbon $\left(\mathrm{CO}_{2}\right)$ variation in the light bottles and corrected for dark $\mathrm{CO}_{2}$ uptake (dark bottles). Net oxygen production, light $\mathrm{CO}_{2}$ fixation, and respiration rates were expressed in volumetric units because the use of that unit was recommended for monitoring the trophic state of coastal ecosystems [33]. The photosynthetic quotient $\left(\mathrm{PQ}=\right.$ moles of $\mathrm{O}_{2}$ produced $\times$ moles of $\mathrm{CO}_{2}$ fixed $^{-1}$ ) was calculated for each site to provide a better view of the balance/unbalance between $\mathrm{O}_{2}$ production and $\mathrm{CO}_{2}$ fixation.

\section{Bacterial Counts and Biomass}

The bacterial density of the samples was determined by filtering $1 \mathrm{~mL}$ of water onto $0.2-\mu \mathrm{m}$ pore size dark polycarbonate filters labeled with the fluorescent DNA stain acridine orange (AO). The filters were mounted on glass slides and stored at $-20^{\circ} \mathrm{C}$ until counting under epifluorescence microscopy [27] on a Zeiss Axioplan equipped with a blue filter set (487709-BP 450-490, FT 510, LT 520) and a CCD Watec (0.0003 lx sensibility). Field images were processed using the UTHSCSA Image Tool (University of Texas Health Science Center, San Antonio, TX, USA) with the Capture X program (X'treme 98 for Windows 98). Cell edges were detected following the filter sequence of $1 \times$ Laplacian, $1 \times$ Gaussian, and $3 \times$ Mean [39], and a minimum of 30 fields of view were counted. Bacterial biovolume (in cubic micrometers) was calculated from the algorithm suggested in Massana et al. [39], and bacterial biomass (in femtograms of C per cell) was estimated using the following algorithm based on the cellular biovolume: $B=120 \times V^{0.7}$, where $B=$ biomass, $V=$ biovolume, and $120=$ conversion factor of carbon (femtograms of C per cubic micrometer) [46].

Because it was difficult to differentiate purple sulfur bacteria (PSB) from nanoflagellates using the AO stain, determination of PSB density was determined from the preserved samples (paraformaldehyde $4 \%$ final concentration $(v / v))$ in Utermöhl sedimentation chambers. Aliquots of $10 \mathrm{~mL}$ were allowed to settle for $24 \mathrm{~h} \mathrm{[58]} \mathrm{and} \mathrm{then} \mathrm{counted}$ on an inverted ZEISS Axiovert-135 microscope equipped with phase contrast. However, the data presented here are only the results from the bottom water of site 33 to show the contribution of PSB to total bacterial density.

\section{Bacterial Community Structure and Statistical Analyses}

For determination of the bacterial community structure, $50-\mathrm{mL}$ samples were pre-filtered through a $25-\mathrm{mm}$ GF/A filter (Whatman, 1.6- $\mu \mathrm{m}$ nominal retention) to remove large eukaryotic cells. We are aware that this pre-filtration might have removed most of the PSB bacteria (larger than $1.6 \mu \mathrm{m}$ ); however, this procedure is necessary to avoid non-specific DNA extraction of eukaryotic microorganisms, such as phytoplankton, that have chloroplasts that could mislead the interpretation of the results. Picophytoplankton $(0.2-2 \mu \mathrm{m})$ could pass the filter, but they would not be expected to be abundant in such eutrophic system [17]. Ten milliliters of the 
pre-filtered samples were filtered onto $25-\mathrm{mm}$ Supor 200 (Pall Co., East Hills, NY, USA) $0.2-\mu \mathrm{m}$ polysulfone filters. These filters were stored in $130 \mu \mathrm{L}$ of Qiagen DNA lysis buffer AL and frozen at $-20^{\circ} \mathrm{C}$. Samples were transported on dry ice to the USA, where DNA extraction and denaturing gradient gel electrophoresis (DGGE) were performed. Total cellular nucleic acids were extracted from the picoplankton samples using the DNeasy tissue kit (Qiagen, Chattsworth, CA, USA) following the manufacturer's protocol with small modifications [54]. The rRNA genes were amplified from total genomic DNA by PCR using two general bacterial primers: $358 \mathrm{~F}-\mathrm{GC}$ and 517R (5'-CGCCCGC CGCGCGCGGCGGGCGGGGCGGGGGCACGGGGGG CCTACGGGAGGCAGCAG-3' and 5'-ATTACCGC GGCTGCTGG-3') in a PTC-200 thermal cycler (MJ Research, Watertown, MA, USA) [43]. The PCR cycling conditions included an initial 4-min denaturation step at $94^{\circ} \mathrm{C}$, which was followed by a three-step cycle consisting of $1 \mathrm{~min}$ of denaturation at $94^{\circ} \mathrm{C}, 1 \mathrm{~min}$ of annealing at $50^{\circ} \mathrm{C}$, and $1 \mathrm{~min}$ of extension at $68^{\circ} \mathrm{C}$. The cycle was repeated 35 times. The reaction concluded with a 10 -min extension at $68^{\circ} \mathrm{C}$. The reaction mixture contained $2.0 \mathrm{mM} \mathrm{MgCl} 2,0.25 \mathrm{mM}$ dNTPs, $10 \mu \mathrm{M}$ of each primer, $3 \mu \mathrm{L}$ of a bovine serum albumin (stock concentration of $10 \mathrm{mg} \mathrm{mL}^{-1}$; Sigma-7030), and $1 \mathrm{U}$ of Bio-x-act DNA polymerase (Bioline) in a total volume of $25 \mu \mathrm{L}$. The PCR amplicons were analyzed with DGGE, with a gel concentration of $8 \%$ and denaturing gradients (urea/ formamide) of $25 \%$ and $55 \%$. Electrophoresis was performed at $60^{\circ} \mathrm{C}$ for $20 \mathrm{~h}$ at $100 \mathrm{~V}$ using a DCode DGGE apparatus (Bio-Rad, Hercules, CA, USA). After staining with ethidium bromide, the gel image was digitized and processed using Kodak Molecular Imaging software 4.5 (Eastman Kodak Inc), Gel Logic 100 electrophoresis documentation, and analysis system for recognizing bands and determining band migration distances. Analysis of band distances was done using the Palaeontological Statistics data analysis package [25]. The presence/absence of band patterns was used to define bacterial assemblages within a sample, since no significant difference was observed between analysis of intensity of bands and presence-absence [12]. A band was considered to be present when its band intensity was higher than $5 \%$ of the peak height of the darkest band in the lane using the same image software. At least three independent PCR amplifications of each sample followed by DGGE were carried out, and extreme care was taken to consider only the bands that occurred in all gel repeats. Bacterial communities were compared based on the presence and absence of bands in surface and bottom samples that were representative of the lagoon (stations 12,33 , and 82; Fig. 1) during the two sampling times representing different oxygen concentrations.

Analysis of variance (ANOVA) and principal components analysis (PCA) were applied to environmental and biotic data (primary production and community respiration). Data were log-transformed to achieve the assumptions of normality and homoscedasticity [63]. Homogeneous groups were tested with the post hoc HSD test for unequal N [57]. ANOVA analyses and PCA were generated using STATISTICA 7.0 (Statsoft, Tulsa, OK, USA).

\section{Results}

Physicochemical Characterization of the System

Water temperature averaged $27.2 \pm 0.8^{\circ} \mathrm{C}$ in summer and $23.6 \pm 2.8^{\circ} \mathrm{C}$ in fall, representing a significant decrease $(p=<0.001, n=36$; Table 1$)$. Salinity averaged $27.9 \pm 2.5$ in summer and $29.9 \pm 2$ in fall, which was a significant increase in the fall ( $X$ test $p<0.01, n=36$ ). Spatially, temperature varied horizontally (lower values in the northern sector, presenting a $8.7^{\circ} \mathrm{C}$ variability in fall) and only slightly over depth. Therefore, salinity was higher in the bottom waters compared to surface at most stations, making this variable responsible for stratification in the system, as stated by [20]. Salinity minimum and maximum values were measured in southern and central sectors, respectively, in both seasons (Table 1). The stratification index increased significantly with time only in the central sector ( $p=0.013, n=8$; Fig. 2 c, d). There was a small vertical inversion in the salinity of southern and northern sectors, which had already been reported, and this is linked to infiltration of the groundwater [47]. Secchi disk depth averaged $2.7 \pm 0.7 \mathrm{~m}$ in both periods, with significantly lower values in the more enclosed area (south; $p<0.001, n=18$ ). The water column of the southern sector was more turbid in the fall, while the central sector was clearer (Table 1). Accordingly, the lowest and the highest PAR reaching the bottom waters $\left(\mathrm{PAR}_{\mathrm{b}}\right)$ were estimated in the corresponding sectors. The bottom waters of the stratified station 33 received one of the lowest radiation levels in the fall, $4 \mu \mathrm{mol}$ quanta $\mathrm{m}^{-2} \mathrm{~s}^{-1}$ (Fig. 2a, b). Dissolved oxygen ranged from $0.38 \mathrm{mg} \mathrm{L}^{-1}$ (central—bottom waters of station 33) to $7.7 \mathrm{mg} \mathrm{L}^{-1}$ (south-surface waters; Fig. 2e, f). Vertically, DO decreased significantly with depth (Fig. 2e, f; $p<0.001, n=36$ ), with hypoxic and suboxic waters only being found in the central sector in fall (Fig. 2f). Among dissolved inorganic nitrogen (DIN), ammonium $\left(\mathrm{NH}_{4}{ }^{+}\right)$was the dominant form, comprising $89 \%$ of total DIN. $\mathrm{NH}_{4}^{+}$ averaged 3.96 \pm 2.40 in summer and $13.10 \pm 14.94 \mu \mathrm{mol} \mathrm{L}^{-1}$ in fall, increasing toward the bottom suboxic waters of station 33 and the northern part of the lagoon in fall (Table 1). This was the only nutrient that showed vertical variation (ANOVA with surface $\times$ bottom, $p=0.005$ ). Nitrate plus nitrite $\left(\mathrm{NO}_{3}{ }^{-}+\mathrm{NO}_{2}{ }^{-}\right)$averaged $0.99 \pm 0.94 \mu \mathrm{mol} \mathrm{L}{ }^{-1}$, and phosphate averaged $0.73 \pm 0.58 \mu \mathrm{mol} \mathrm{L}^{-1}$, in both seasons. Silicate averaged $27.28 \pm 19.21 \mu \mathrm{mol} \mathrm{L}^{-1}$ in summer and $49.97 \pm 45.30 \mu \mathrm{mol} \mathrm{L} \mathrm{L}^{-1}$ in fall. In summer, silicate 
Table 1 Water column depth, transparency (= Secchi depth), temperature, salinity, ammonium, nitrate plus nitrite, phosphate, and silicate measured in the surface and bottom waters of Conceição Lagoon in summer and fall of 2007

\begin{tabular}{|c|c|c|c|c|c|c|c|c|c|}
\hline Season & Sample & Depth (m) & Transp. (m) & $T$ & Salinity & $\mathrm{NH}_{4}^{+}(\mu \mathrm{M})$ & $\mathrm{NO}_{3}^{-}+\mathrm{NO}_{2}^{-}(\mu \mathrm{M})$ & $\mathrm{PO}_{4}{ }^{3-}(\mu \mathrm{M})$ & $\mathrm{SiO}_{4}{ }^{2-}(\mu \mathrm{M})$ \\
\hline \multirow[t]{18}{*}{ Summer } & 6 surface & 3.0 & 1.58 & 28.20 & 25.50 & 7.34 & 0.43 & 2.19 & 58.92 \\
\hline & 6 bottom & & & 27.70 & 25.70 & 6.00 & 0.55 & 1.85 & 66.00 \\
\hline & 12 surface & 5.4 & 1.80 & 27.80 & 25.60 & 1.58 & 0.30 & 0.43 & 42.17 \\
\hline & 12 bottom & & & 26.90 & 25.00 & 6.44 & 0.89 & 1.26 & 74.66 \\
\hline & 20 surface & 5.4 & 2.00 & 27.60 & 25.70 & 0.01 & 2.93 & 0.09 & 49.64 \\
\hline & 20 bottom & & & 27.00 & 25.10 & 4.62 & 0.35 & 1.02 & 34.50 \\
\hline & 33 surface & 5.6 & 2.60 & 28.80 & 29.80 & 2.51 & 0.65 & 0.09 & 31.27 \\
\hline & 33 bottom & & & 27.00 & 32.10 & 3.24 & 0.48 & 0.73 & 26.02 \\
\hline & 37 surface & 5.0 & 3.20 & 28.50 & 30.00 & 4.68 & 4.73 & 2.00 & 10.08 \\
\hline & 37 bottom & & & 27.20 & 31.50 & 2.31 & 1.02 & 0.39 & 10.08 \\
\hline & 49 surface & 4.0 & 3.40 & 26.90 & 29.90 & 2.28 & 0.77 & 0.09 & 14.92 \\
\hline & 49 bottom & & & 26.10 & 31.00 & 8.68 & 0.36 & 0.48 & 22.59 \\
\hline & 53 surface & 5.1 & 3.70 & 26.80 & 30.40 & 2.03 & 1.04 & 0.82 & 5.04 \\
\hline & 53 bottom & & & 26.00 & 32.50 & 2.86 & 1.08 & 0.78 & 19.36 \\
\hline & 64 surface & 4.9 & 4.20 & 26.80 & 28.20 & 6.44 & 0.20 & 2.04 & 20.17 \\
\hline & 64 bottom & & & 27.60 & 26.90 & 6.38 & 0.27 & 1.36 & 12.50 \\
\hline & 82 surface & 6.7 & 3.00 & 26.40 & 27.50 & 1.71 & 0.63 & 0.09 & 13.11 \\
\hline & 82 bottom & & & 26.10 & 27.20 & 4.30 & 0.21 & 0.96 & 18.76 \\
\hline \multirow[t]{18}{*}{ Fall } & 6 surface & 3.6 & 2.20 & 26.00 & 26.20 & 8.36 & 0.55 & 0.53 & 163.51 \\
\hline & 6 bottom & & & 26.90 & 26.30 & 10.51 & 1.80 & 0.43 & 155.64 \\
\hline & 12 surface & 5.4 & 1.76 & 23.60 & 26.70 & 1.19 & 0.66 & 1.02 & 3.27 \\
\hline & 12 bottom & & & 23.60 & 27.10 & 2.44 & 0.58 & 1.22 & 18.81 \\
\hline & 20 surface & 5.2 & 2.17 & 26.60 & 26.10 & 6.92 & 0.89 & 1.22 & 0.25 \\
\hline & 20 bottom & & & 26.60 & 26.90 & 10.12 & 1.67 & 0.78 & 25.67 \\
\hline & 33 surface & 5.6 & 2.72 & 23.30 & 30.90 & 0.62 & 3.19 & 0.39 & 46.26 \\
\hline & 33 bottom & & & 23.60 & 33.80 & 17.93 & 0.63 & 0.53 & 95.30 \\
\hline & 37 surface & 5.2 & 2.60 & 24.90 & 30.40 & 4.81 & 1.05 & 0.58 & 36.77 \\
\hline & 37 bottom & & & 24.80 & 34.00 & 0.30 & 0.80 & 0.09 & 36.77 \\
\hline & 49 surface & 4.8 & 2.72 & 25.10 & 30.10 & 2.83 & 0.77 & 0.43 & 30.92 \\
\hline & 49 bottom & & & 25.30 & 33.40 & 7.75 & 0.52 & 0.39 & 51.10 \\
\hline & 53 surface & 5.4 & 3.20 & 24.70 & 29.50 & 1.87 & 0.44 & 1.22 & 34.15 \\
\hline & 53 bottom & & & 24.90 & 34.10 & 12.43 & 0.41 & 1.17 & 68.86 \\
\hline & 64 surface & 5.1 & 2.80 & 18.90 & 30.60 & 21.77 & 0.84 & 0.04 & 36.98 \\
\hline & 64 bottom & & & 18.90 & 30.40 & 53.71 & 0.53 & 0.14 & 27.89 \\
\hline & 82 surface & 7.0 & 3.40 & 19.00 & 30.70 & 34.79 & 1.95 & 0.14 & 37.58 \\
\hline & 82 bottom & & & 18.10 & 30.90 & 37.54 & 0.91 & 0.24 & 29.71 \\
\hline
\end{tabular}

displayed a southward enhancement, while in fall, the highest values were measured in the oxic surface and bottom waters of site 12 and in the suboxic bottom waters of site 33 (163.5, 155.6, and $95.3 \mu \mathrm{M}$, respectively; Table 1).

Spatiotemporal Variability of Oxygenic and Anoxygenic Phototrophic Biomass

Chl $a$ showed a small seasonal variation, averaging $4.28 \mu \mathrm{g} \mathrm{L}^{-1}$ (1.41-8.24 range) in summer (Fig. 3a) and
$5.05 \mu \mathrm{g} \mathrm{L}^{-1}$ (2.35-12.43 range) in fall (Fig. 3a, b). The maximum value was measured in the bottom waters of site 33 in fall $\left(12.43 \mu \mathrm{g} \mathrm{L}^{-1}\right)$. In contrast, BChl $a$ increased significantly (three-fold) from summer to fall, averaging $0.89 \mu \mathrm{g} \mathrm{L}^{-1}$ (below the detection limit-5.3 range) in summer and $2.23 \mu \mathrm{g} \mathrm{L}^{-1}$ (below the detection limit-10.40 range) in fall. In both seasons, a pronounced peak occurred at $5 \mathrm{~m}$ deep at site 33. These $\mathrm{BChl} a$ peaks and, remarkably, the $\mathrm{Chl}$ $a$ peak at site 33 in fall were associated with suboxia (Figs. $2 \mathrm{f}$ and $3 \mathrm{~b}, \mathrm{~d})$. Furthermore, the $\mathrm{BChl} a / \mathrm{Chl} a$ ratios averaged 

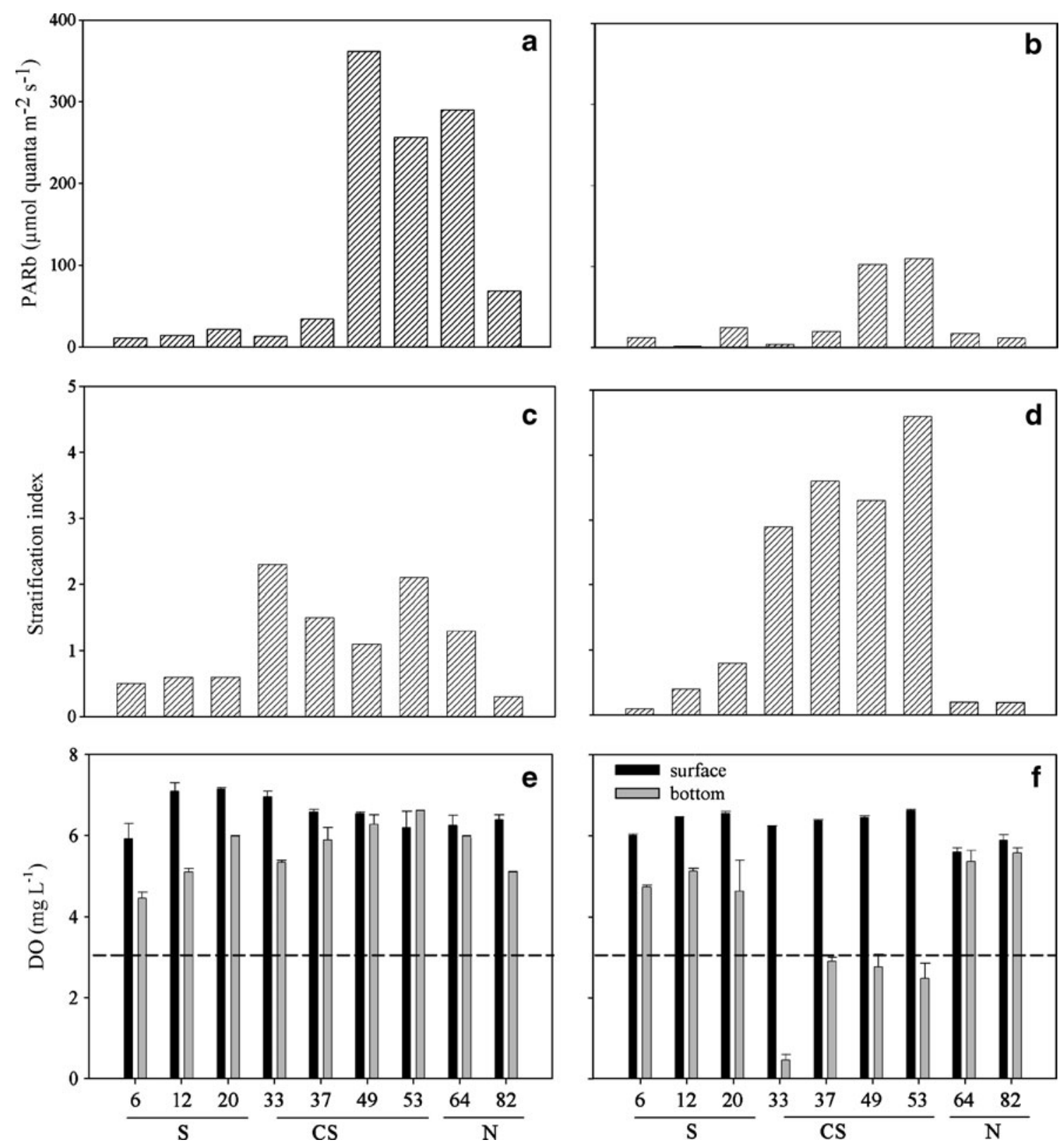

Figure 2 Spatial variability of bottom water PAR (micromoles quanta per square meter per second), stratification index, and DO (milligrams per liter) in summer (a, c, e) and in fall $2007(\mathbf{b}, \mathbf{d}, \mathbf{f})$. e, f DO in the

surface and bottom water layers. Error bars represent standard deviations, $n=3$. Dashed line shows the $\mathrm{DO}=3 \mathrm{mg} \mathrm{L}^{-1}$ used here to define the limit for hypoxia

$0.15 \pm 0.12$ in summer and $0.27 \pm 0.13$ in fall (a two-fold increase) with maximum ratios found in the central sector (bottom of site 33) and in the southern sector (surface of site $12 ; 0.40)$ in fall (Table 2).

Spatiotemporal Variability of Primary Production

\section{Light $\mathrm{CO}_{2}$ Fixation ( $\mathrm{CO}_{2}$ Fixation)}

Light $\mathrm{CO}_{2}$ fixation averaged $52.5 \mathrm{mg} \mathrm{C} \mathrm{m}^{-3} \mathrm{~h}^{-1}$ (4.2 at site 82-232.3 $\mathrm{mg} \mathrm{C} \mathrm{m}^{-3} \mathrm{~h}^{-1}$ at site 6) in summer (Fig. 4a) and $108.5 \mathrm{mg} \mathrm{C} \mathrm{m}^{-3} \mathrm{~h}^{-1}$ in fall (10.1 at site $82-381.0 \mathrm{mg} \mathrm{C} \mathrm{m}^{-3} \mathrm{~h}^{-1}$ at

site 6; Fig. 4b), representing a two-fold temporal increase. In general, $\mathrm{CO}_{2}$ fixation was higher in oxygenated surface waters (Fig. 4a, b), but if only the bottom waters are considered, the suboxic layers were significantly higher than the oxic and hypoxic layers. The maximum fixation rates were estimated in the most turbid waters of the southern sector, the enclosed area (Fig. 4a, b; Table 1). The bottom suboxic waters of site 33 also displayed high $\mathrm{CO}_{2}$ fixation rates (up to $223.0 \mathrm{mg} \mathrm{C} \mathrm{m}^{-3} \mathrm{~h}^{-1}$; Fig. 4b), which occurred under the PAR of only $4 \mu \mathrm{mol} \mathrm{m}{ }^{-2} \mathrm{~s}^{-1}$. Phototrophic PSB were observed only in suboxic waters of site 33 (Fig. 4). 

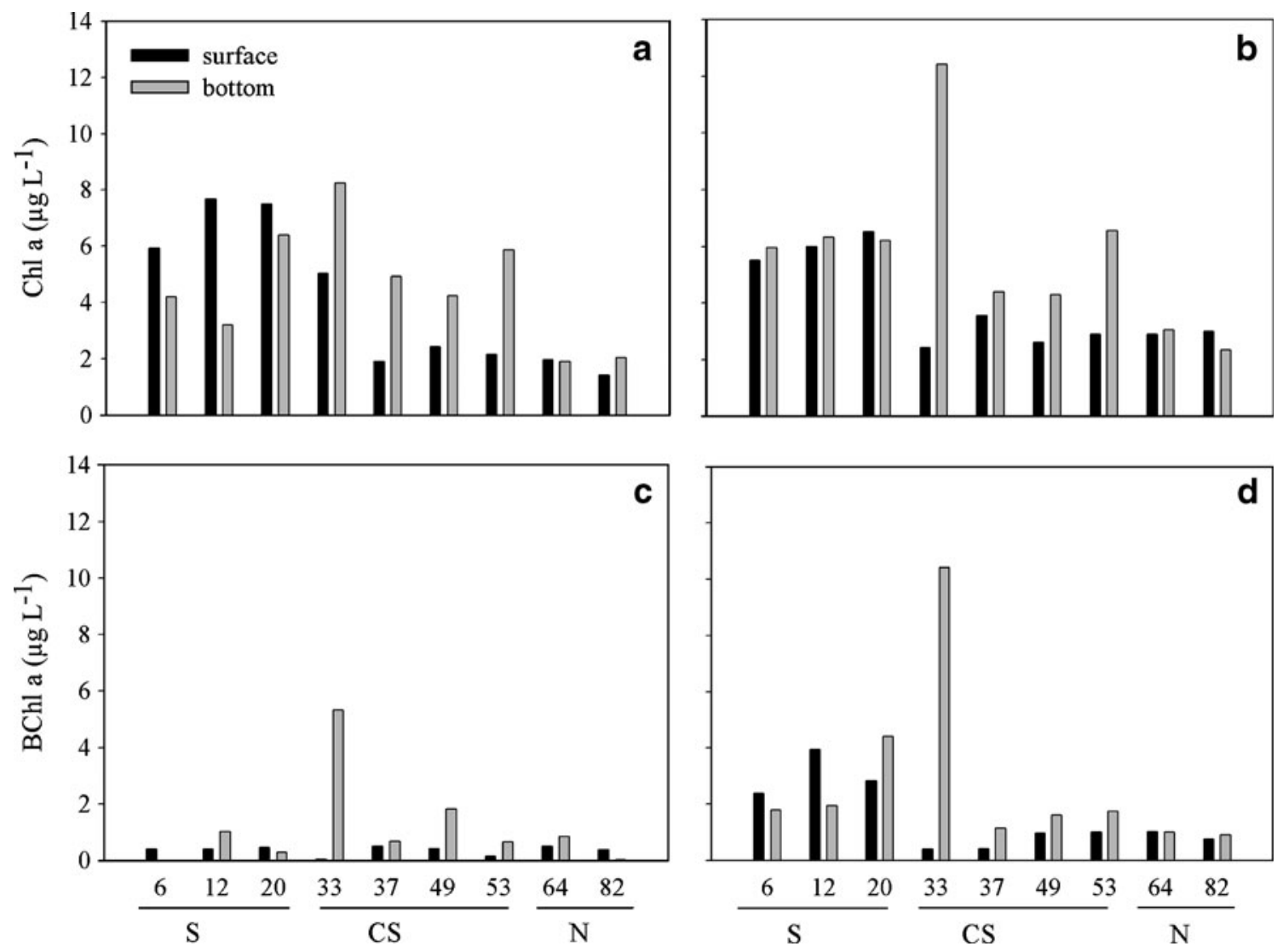

Figure 3 Spatial variability of photosynthetic pigments: chlorophyll $a(C h l a)$ in summer (a) and fall (b), bacteriochlorophyll $a(B C h l a)$ in summer (c) and fall (d). Surface stands for water collected $0.5 \mathrm{~m}$ below surface, and bottom stands for water collected $0.5 \mathrm{~m}$ above the sediment surface

\section{Net Oxygen Production}

The OP averaged $334.9 \mathrm{mg} \mathrm{O}_{2} \mathrm{~m}^{-3} \mathrm{~h}^{-1}$ in summer and $61.3 \mathrm{mg} \mathrm{O}_{2} \mathrm{~m}^{-3} \mathrm{~h}^{-1}$ in fall, ranging from $12.8 \mathrm{mg} \mathrm{O}_{2} \mathrm{~m}^{-3} \mathrm{~h}^{-1}$ (site 82) to $944.1 \mathrm{mg} \mathrm{O}_{2} \mathrm{~m}^{-3} \mathrm{~h}^{-1}$ (site 6; Fig. 4c) and from $-124.70 \mathrm{mg} \mathrm{O}_{2} \mathrm{~m}^{-3} \mathrm{~h}^{-1}$ (bottom water of site 33) to $228 \mathrm{mg} \mathrm{O}_{2} \mathrm{~m}^{-3} \mathrm{~h}^{-1}$ (site 49; Fig. 4d). On average, oxygen production was higher in oxygenated surface waters (Fig. $4 \mathrm{c}$, d), decreasing 5.5-fold from summer to fall. $\mathrm{OP}$ and $\mathrm{CO}_{2}$ fixation were positively correlated in summer $(r=0.74, n=18$, $p=0.001)$, while in fall, they were not correlated.

The PQ (moles of $\mathrm{O}_{2}$ produced $\times$ moles of $\mathrm{CO}_{2}$ fixed ${ }^{-1}$ ) averaged $2.91 \pm 2.03$ in summer and $0.33 \pm 0.31$ in fall, nine times smaller in fall. The minimum (0.78) and maximum (7.28) PQs were registered in the northern and southern sectors, respectively, in summer, while in fall, the minimum was observed in the central and southern sectors $(-0.02$ at the bottom of 33 and 0.02 at the surface of site $12)$ and the maximum in the central sector (1.33 at surface of site 52; Table 2). The highest discrepancies for $\mathrm{CO}_{2}$ uptake and $\mathrm{O}_{2}$ production were detected in the oxygenated surface waters of site 12 and in the bottom suboxic waters of site 33, both in fall (Fig. 4b, d), which was concomitant with peaks of BChl $a$ and $\mathrm{BChl} a / \mathrm{Chl} a$ ratio (Fig. 3d; Table 2), suggesting the contribution of anoxygenic primary production.
Table 2 Averages of BChl $a / \mathrm{Chl} a$ ratios and PQ in three sectors of the Conceição Lagoon in summer and fall of 2007

Values in brackets correspond to minimum and maximum

\begin{tabular}{llll}
\hline Sampling period & Sector & BChl $a /$ Chl $a$ ratio & PQ \\
\hline Summer & South & $0.08(0.01-0.24)$ & $3.18(0.81-7.28)$ \\
& Central & $0.16(0.01-0.39)$ & $2.32(0.86-4.59)$ \\
& North & $0.18(0.01-0.30)$ & $3.11(0.78-6.85)$ \\
Fall & South & $0.31(0.24-0.40)$ & $0.29(0.02-0.58)$ \\
& Central & $0.24(0.10-0.45)$ & $0.38(-0.02-1.33)$ \\
& North & $0.24(0.20-0.28)$ & $0.23(0.12-0.43)$ \\
\hline
\end{tabular}




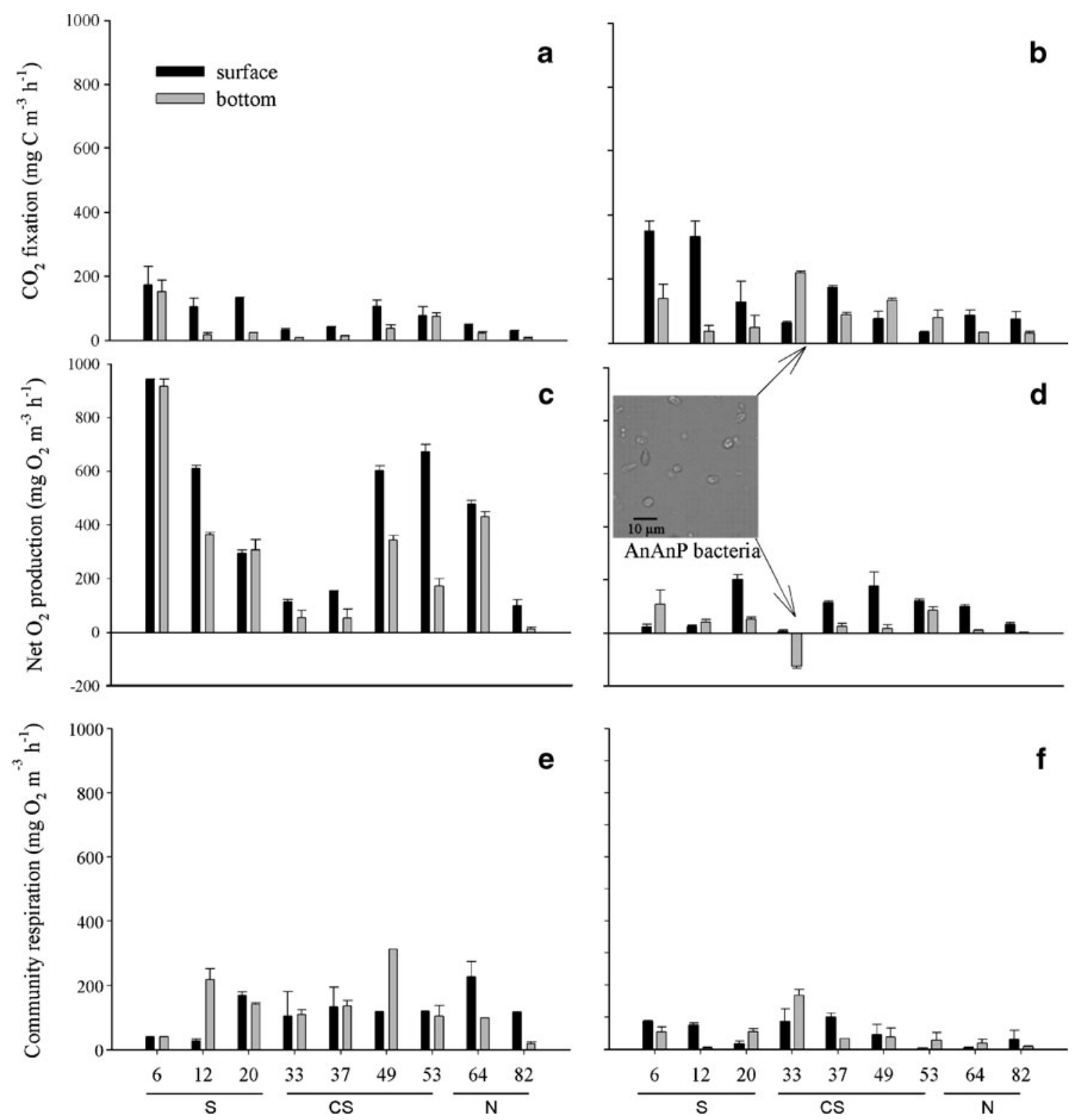

Figure 4 Spatial variability of light $\mathrm{CO}_{2}$ fixation calculated by ${ }^{14} \mathrm{C}$ method $\left(\mathrm{CO}_{2}\right.$ fixation), net oxygen production, and planktonic community respiration calculated by $\mathrm{O}_{2}$ method in summer $(\mathbf{a}, \mathbf{c}, \mathbf{e})$ and fall $(\mathbf{b}, \mathbf{d}, \mathbf{f})$. Error bars are SD of two replicates. Surface stands

Spatiotemporal Variability of Planktonic Community Respiration

Planktonic community respiration $(\mathrm{CR}=$ oxygen consumption) averaged $128.74 \mathrm{mg} \mathrm{O}_{2} \mathrm{~m}^{-3} \mathrm{~h}^{-1}$ in summer and $51.4 \mathrm{mg} \mathrm{O}_{2} \mathrm{~m}^{-3} \mathrm{~h}^{-1}$ in fall (a 2.5 -fold temporal decrease), ranging from $12.9 \mathrm{mg} \mathrm{O} \mathrm{m}^{-3} \mathrm{~h}^{-1}$ (site 82) to $312.4 \mathrm{mg} \mathrm{O}_{2} \mathrm{~m}^{-3} \mathrm{~h}^{-1}$ (site 49) in summer (Fig. 4e) and from $3.7 \mathrm{mg} \mathrm{O}_{2} \mathrm{~m}^{-3} \mathrm{~h}^{-1}$ (site 12) to $169.06 \mathrm{mg} \mathrm{O}_{2} \mathrm{~m}^{-3} \mathrm{~h}^{-1}$ (site 33 ) in fall (Fig. 4f), with significantly higher values in suboxic bottom waters compared to oxic and hypoxic for water collected $0.5 \mathrm{~m}$ below the surface, and bottom stands for $0.5 \mathrm{~m}$ above the sediment. Photograph of sulfur phototrophic bacteria found in suboxic bottom water, demonstrating the intracellular sulfur grains. Image is resulted from a $\times 1,000$ cell magnification

layers (ANOVA result). A positive relationship between $\mathrm{CR}$ and $\mathrm{CO}_{2}$ fixation in fall $(r=0.68, n=18, p=0.002)$ confirmed their similar spatial distribution.

\section{Bacteria Counts and Biomass}

Total bacterial density in the bottom waters of site 33 averaged $3.52 \times 10^{6}$ cells $\mathrm{mL}^{-1}$ in summer and $4.0 \times$ $10^{6}$ cells $\mathrm{mL}^{-1}$ in fall, which was approximately 500,000 more cells $\mathrm{mL}^{-1}$. PSB were detected only in the suboxic bottom waters during the fall season, as shown in Fig. 4d, 
with a density $4.83 \times 10^{4}$ cells $\mathrm{mL}^{-1}$. These PSB bacteria are easy to identify under regular light microscope due to their intracellular sulfur grains (Fig. 4d). Their relative density averaged $1.2 \%$ of total bacteria, while their biomass averaged $0.04 \mu \mathrm{g} \mathrm{C} \mathrm{mL}$ (bacteria biomass was $0.32 \mu \mathrm{g} \mathrm{C} \mathrm{mL}^{-1}$ ), equivalent to a contribution of $12.2 \%$ of bacterial biomass.
Statistical Analysis

Principal Components Analysis

Figure 5a shows the result from the PCA analysis using the average of abiotic and biotic variables (temperature, salinity, PAR, SEC, DO, ammonium, silicate, Chl $a, \mathrm{BChl}$
Figure 5 PCA plot of sites in both summer and fall periods (a), only in summer (b), and only in fall (c). SEC Secchi disk depth (water transparency), PARz PAR in the water column, $T$ temperature, $S A L$ salinity, $\mathrm{DO}$ dissolved oxygen, $\mathrm{NH}_{4}^{+}$ ammonium, $\mathrm{NO}_{3}{ }^{-}$nitrate + nitrite, $\mathrm{PO}_{4}{ }^{3}$ phosphate, $\mathrm{SIL}$ silicate, $C H L$ chlorophyll $a$, $B C H L$ bacteriochlorophyll $a$, $\mathrm{CO}_{2} f$ light $\mathrm{CO}_{2}$ fixation, $\mathrm{CR}$ community respiration, $O P$ net oxygen production. The black and gray circles in the panels show the variables that better correlated with $\mathrm{CO}_{2}$ fixation and oxygen production in summer and fall

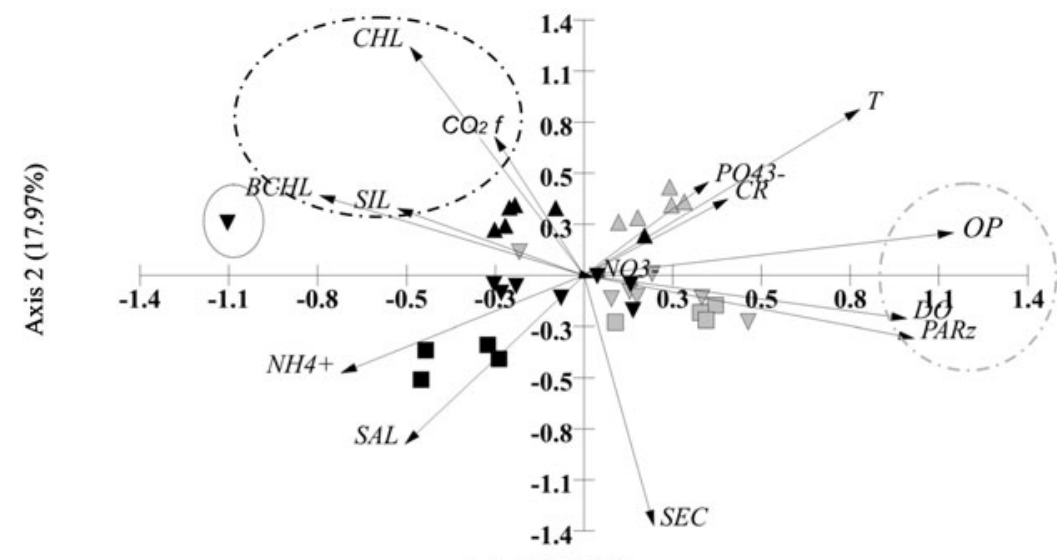

$\triangle \mathrm{S}$ summer

$\nabla$ CS summer

N summer

A S fall

v CS fall

Axis $1(26.11 \%)$

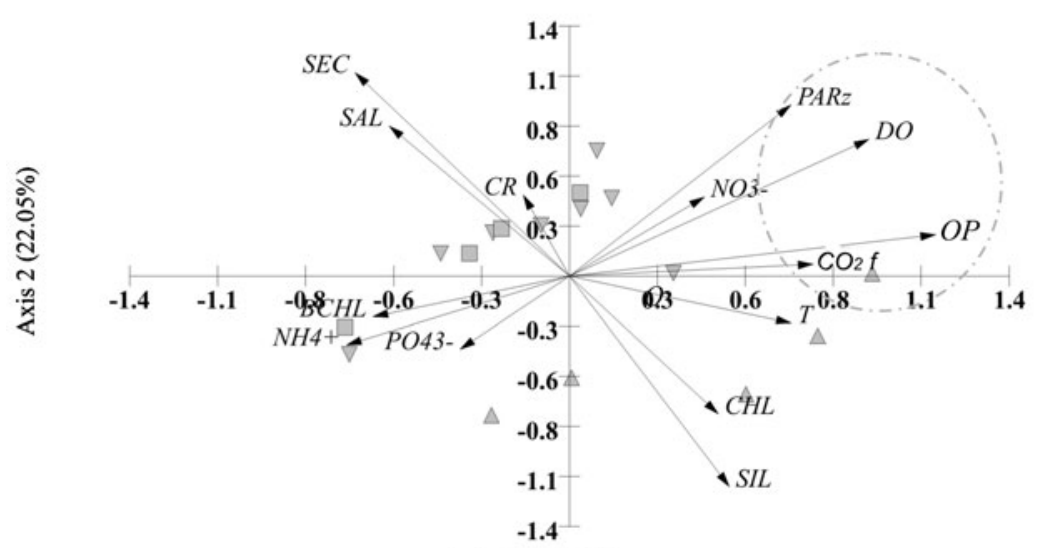

$\triangle \quad$ S summer

$\nabla$ CS summer

N summer

Axis $1(25.19 \%)$

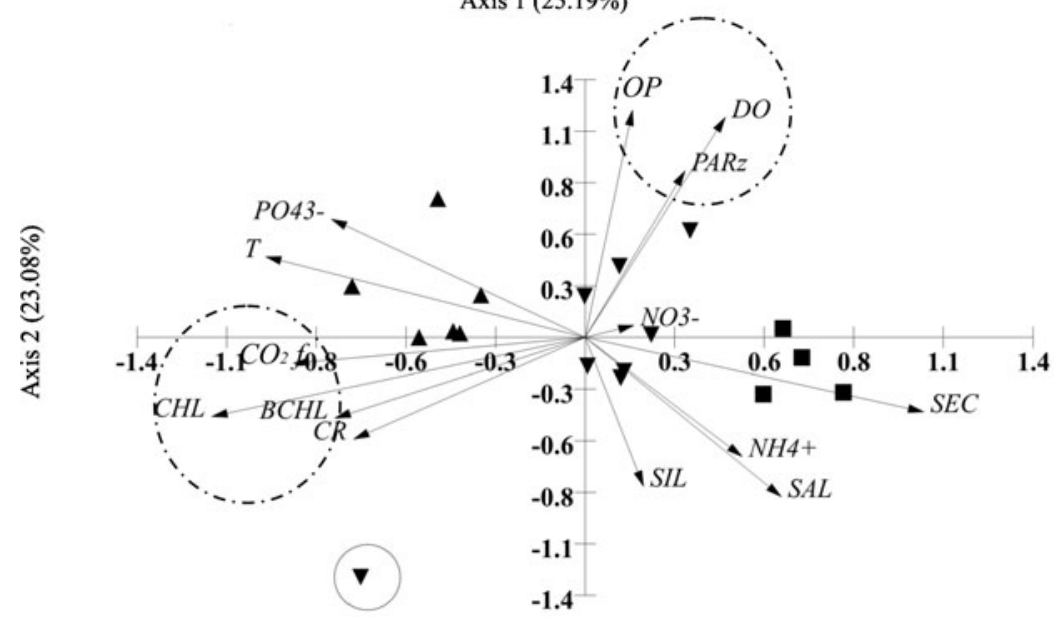

C

Axis 1 (28.15\%) 
$a$, OP, $\mathrm{CR}$, and light $\mathrm{CO}_{2}$ fixation) of each sample (representing $44.1 \%$ of total data variance; Table 3). Axis 1 was related to temporal variability (Fig. 5a) and axis 2 to spatial variability within the data that separated the samples of the enclosed southern sector from those of the other sectors. Temperature, PARz, DO, and OP presented the highest positive loads on axis 1 , being related to the summer group (January/February), while BChl $a$ and, to a smaller degree, ammonium showed the highest negative loads (explaining the fall group). Regarding the special variability, axis $2, \mathrm{Chl} a$, temperature, and $\mathrm{CO}_{2}$ fixation had the highest positive loadings, while Secchi disk depth and salinity had the highest negative values (Table 3 ). Panels b and $\mathrm{c}$ show the spatial ordination of samples and variables in summer (Fig. 5b) and in fall (Fig. 5c) to facilitate the interpretation of spatial variability within periods.

In summer, $47.2 \%$ of the total variance was explained by the two axes. Axis 1 was related to light $\mathrm{CO}_{2}$ fixation, OP, $\mathrm{DO}, T$, ammonium, SEC, and PAR, grouping southern sector samples on the positive side and central and northern samples on the negative side (Fig. 5b). On axis 2, the central and northern sectors were separated from the south, mainly by SEC, PAR, salinity, and DO with the highest positive loadings and by silicate and $\mathrm{Chl} a$ with negative loadings.

In fall, $51.2 \%$ of the total variance was explained by the two axes (Fig. 5c). Axis 1 was related to SEC, $\mathrm{Chl} a, \mathrm{CO}_{2}$ fixation, $T, \mathrm{PO}_{4}{ }^{3-}, \mathrm{BChl} a$, and $\mathrm{CR}$, separating the northern samples on the negative side and the group of southern sites on the positive side. Salinity and silicate represented the lowest values on axis 2 (Fig. 5c; Table 3). The black circled upside-down triangle symbol that is shown in panels a and $\mathrm{c}$ represents the isolated suboxic bottom waters of site 33, which was negatively related to OP, DO, and PAR in panel c.

\section{Cluster Analysis of Bacterial Communities}

A total of 48 bands were represented on the DGGE gel, 20 of which were present in all samples. Cluster analysis of DGGE banding patterns showed that the bacterial community structure of suboxic waters at site 33 was similar to that of oxic waters at site 12 (surface and bottom waters) in May (group 1). The remaining nine sites were clustered into group 2, which contained all samples with oxygen concentrations $>3 \mathrm{mg} \mathrm{L}^{-1}$, coupled with $\mathrm{NOP}$ and $\mathrm{CO}_{2}$ fixation (Figs. 2e-f, 4a-d, and 6). This grouping suggests that the bacterial community structures of suboxic waters were more similar to those of the oxic waters of station 12 in May than to surface waters at the same location. In addition, the bacterial assemblages within group 1 sites showed a higher temporal variability.

\section{Discussion}

In general, Chl $a$ measured in this study presented a similar spatial distribution as formerly described for Conceição Lagoon, i.e., higher values in the south and bottom waters of central sectors and low concentrations toward the north $[16,18,20,47]$. Enhanced water residence time of southern sector and deeper portion of central sector would justify the accumulation of Chl $a$ in these areas. Odebrecht and Caruso [47] observed that the central sector functions as a sediment trap, collecting organic matter produced inside the lagoon and from freshwater origins. It is likely that sedimentation in this region is accelerated by the differences in salinity between the surface and the bottom, which promotes the aggregation of fine particles. The stabilization of the water
Table 3 PCA variable loadings for axes 1 and 2

The percentage of variance explained by two axes are shown in italic, and letters A, $\mathrm{B}$, and $\mathrm{C}$ are related to the correspondent panels in Fig. 5 . The most significant loadings are shown in bold

\begin{tabular}{|c|c|c|c|c|c|c|}
\hline & $\begin{array}{l}\text { Axis } 1 \\
26.11 \% \\
\text { A }\end{array}$ & $\begin{array}{l}\text { Axis } 2 \\
17.97 \% \\
\text { A }\end{array}$ & $\begin{array}{l}\text { Axis } 1 \\
25.19 \% \\
\text { B }\end{array}$ & $\begin{array}{l}\text { Axis } 2 \\
22.05 \% \\
\text { B }\end{array}$ & $\begin{array}{l}\text { Axis } 1 \\
28.15 \% \\
\text { C }\end{array}$ & $\begin{array}{l}\text { Axis } 2 \\
23.08 \% \\
\text { C }\end{array}$ \\
\hline SEC & 0.083 & -0.519 & -0.270 & 0.451 & 0.399 & -0.152 \\
\hline PAR & 0.394 & -0.130 & 0.279 & 0.379 & 0.118 & 0.341 \\
\hline$T$ & 0.329 & 0.344 & 0.280 & -0.104 & -0.376 & 0.165 \\
\hline SAL & -0.214 & -0.349 & -0.227 & 0.333 & 0.231 & -0.325 \\
\hline DO & 0.386 & -0.090 & 0.378 & 0.303 & 0.165 & 0.450 \\
\hline $\mathrm{NH}_{4}^{+}$ & -0.290 & -0.202 & -0.282 & -0.152 & 0.185 & -0.243 \\
\hline $\mathrm{NO}_{3}^{-}$ & 0.013 & -0.005 & 0.170 & 0.175 & 0.058 & 0.025 \\
\hline $\mathrm{PO}_{4}{ }^{3-}$ & 0.149 & 0.194 & -0.138 & -0.162 & -0.298 & 0.242 \\
\hline SIL & -0.223 & 0.139 & 0.202 & -0.466 & 0.069 & -0.304 \\
\hline Chl a & -0.208 & 0.474 & 0.188 & -0.305 & -0.439 & -0.161 \\
\hline BChl a & -0.316 & 0.166 & -0.248 & -0.090 & -0.294 & -0.165 \\
\hline NOP & 0.441 & 0.088 & 0.307 & 0.026 & 0.056 & 0.465 \\
\hline $\mathrm{CR}$ & 0.172 & 0.158 & -0.058 & 0.180 & -0.273 & -0.207 \\
\hline TPP & -0.107 & 0.288 & 0.462 & 0.092 & -0.343 & -0.053 \\
\hline
\end{tabular}




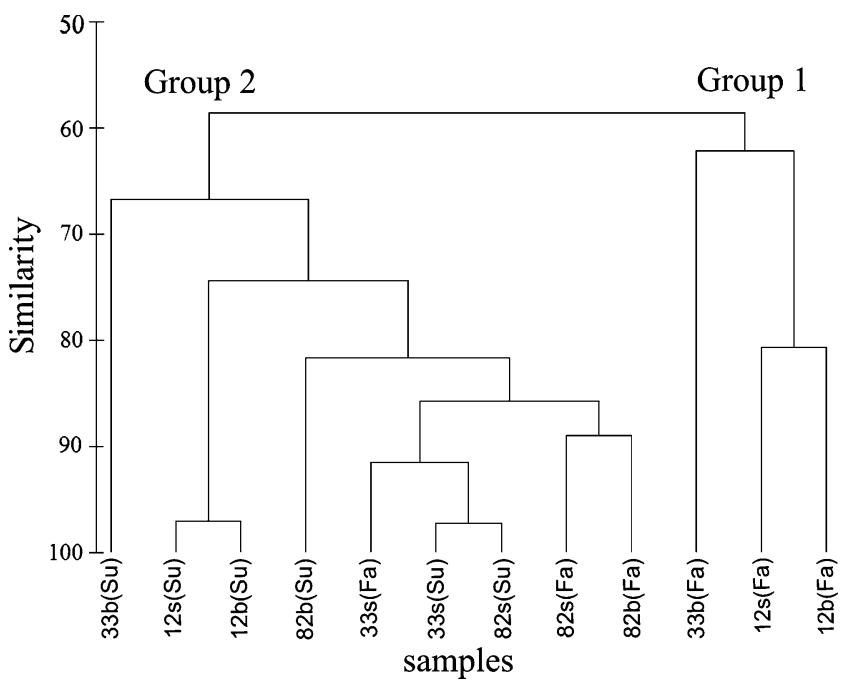

Figure 6 Dendogram constructed from cluster analysis of the DGGE banding patterns based on a binary matrix (presence/absence-Jaccard equation). Numbers 12, 33, and 82 are sample sites representing three sectors $(12=$ south, $33=$ central, $82=$ north $)$; lowercase letters indicate water layer: $s$ surface water, $b$ bottom water; letters in brackets indicate sampling period: $S u$ summer and Fa fall of 2007

column and accumulation of organic matter would lead to high oxygen consumption rates and nutrient mineralization, as indicated by the observation of suboxia and the high silicate concentration in the bottom water of the central stations in fall (Table 1). Water column stratification due to saltwater intrusion is a common feature of the central region of Conceição Lagoon. However, at the southern and northern sectors, an inverted stratification (less saline water at the bottom) has been observed as a result of underground freshwater input $[3,18,47]$.

While Chl $a$ is the photosynthetic pigment synthesized by all oxygenic photoautotrophs allowing them to fix $\mathrm{CO}_{2}$ through the Calvin-Benson cycle, $\mathrm{BChl} a$ is synthesized by a more diverse assemblage of bacteria, including some that do not fix $\mathrm{CO}_{2}$, which may complicate the interpretation of the $\mathrm{BChl} a-\mathrm{Chl} a$ ratio. These bacteria are known as AAnP bacteria due to their lack of ribulose-1,5-bisphosphate carboxylase/oxygenase (RuBisCO) and to their ability to get energy out of photons and fixed carbon out of organic substances [22, 35, 62]. In contrast, the other group of the BChl $a$-containing type of bacteria, the AnAnP bacteria, possesses $\mathrm{RuBisCO}$ and is capable of $\mathrm{CO}_{2}$ fixation [48, 62]; moreover, these microorganisms are found abundantly in the bottom of the oxycline and in the suboxic waters of shallow stratified lakes, estuaries, and coastal lagoons [8, $21,24,56]$. The method used by these previous authors to estimate the contribution of oxygenic and anoxygenic primary production simultaneously and separately was the ${ }^{14} \mathrm{C}$ method with the addition of 3-(30,40-dichlorophenyl)-1,10-dimethyl urea, an herbicide, to the incubation bottles. Previous authors reported an important contribution of anoxygenic primary production to PP, e.g., $21 \mu \mathrm{mol} \mathrm{L} \mathrm{L}^{-1} \mathrm{~h}^{-1}$ at lake Ciso [24] or up to $35 \%$ of PP [21], $12 \mu \mathrm{mol} \mathrm{L}^{-1} \mathrm{~h}^{-1}$ at Lake Vilar [24], up to $35.8 \mu \mathrm{g} \mathrm{C} \mathrm{L}^{-1} \mathrm{~h}^{-1}$ at lake Estanya [8], and at Solar Lake, up to $91 \%$ of PP was attributed to anoxygenic photosynthetic bacteria [10]. The application of the method should be used for future studies in the suboxic waters of the system.

BChl a concentrations in many stratified freshwater lakes are much higher than those found in this study. In temperate lakes, BChl $a$ can reach concentrations as high as $500 \mu \mathrm{g} \mathrm{L}^{-1}[8,15]$, although the values measured in the temperate Massona Lagoon (Spain) of surface BChl $a$ of $1.2 \mu \mathrm{g} \mathrm{L}^{-1}$ and bottom suboxic BChl $a$ of $7.6 \mu \mathrm{g} \mathrm{L}^{-1}$ [8] are in a range similar to those found in Conceição Lagoon. Very low $\mathrm{BChl} a$ concentrations have been reported for oxic coastal systems, such as the Lapalme Lagoon [37], a shelf break of the Mid-Atlantic Bight [11], surface waters of the Baltic Sea [34], and near shore of the Southern California Bight [22], indicating a possible decreasing gradient of $\mathrm{BChl} a$ from anoxic to oxic ecosystems, suggesting that $\mathrm{BChl} a$-containing bacteria are important players in the spreading of dead zones worldwide, specifically in shallow coastal zones.

PCA analysis indicated a positive relationship between Chl $a$ and silicate for the summer period (Fig. 5). In the same period across all of our dataset, $\mathrm{BChl} a$ appeared to be related to phosphate and ammonium. The positive relationship between BChl $a$-containing bacteria and inorganic nitrogen concentrations was first observed in the Delaware and Chesapeake estuaries [60]. However, it is noteworthy that similarly to that study, we found that light seems to play a very important role in the temporal variation of this pigment in Conceição Lagoon. While Chl $a$ did not vary significantly between the sampling periods, $\mathrm{BChl} a$ did vary considerably, with the lowest and the highest values registered during summer and fall, respectively. The enhancement of BChl $a$ at most of the sampling stations followed a substantial decline in the light penetration in the water column of the Lagoon. Higher BChl $a$ synthesis rates by AnAnP bacteria appear to occur under dim light [4, 62]. Similarly, AAnP bacteria have their $\mathrm{BChl} a$ synthesis inhibited by daylight because the pigment is only synthesized in the dark [32, 33].

The influence of light on BChl $a$-containing bacteria seems to have important consequences for the primary production of Conceição Lagoon. During fall, higher rates of carbon dioxide uptake and lower levels of net oxygen production were observed, indicating a decoupling between these processes. This decoupling generated contrasting photosynthetic quotients (PQ; moles of $\mathrm{O}_{2}$ produced/moles of $\mathrm{CO}_{2}$ fixed) in these periods. For instance in summer, $\mathrm{PQ}$ averaged $2.91 \pm 2.03$ with a minimum of 0.78 and a maximum of 7.28 , demonstrating high spatial variability within this period and that, in general, more oxygen was 
produced relative to assimilated carbon. On the contrary, in fall, PQ averaged $0.32 \pm 0.34$ and varied from $-0.02-1.33$, showing a predominance of $\mathrm{CO}_{2}$ fixation over oxygen production, with very little spatial variability. Thus, different from other ecosystems where low PQ values are associated with an enhancement of community respiration $[28,55]$, the decrease of this ratio in Conceição Lagoon in fall was generated by lowering oxygen production and increasing carbon dioxide uptake rates.

The highest community respiration, which was measured in summer, did not lead to anaerobic conditions during this period, while smaller respiration rates led to hypoxic/anoxic conditions in fall, which can be explained by the decrease in OP rates. This would explain the phenomenon observed by Fontes and Abreu [20], who reported oxygen-rich bottom waters in the summer (January) and hypoxic conditions in the winter (July), both of which were measured in the highly stratified water column, which was associated with the amount of light available to photoautotrophic organisms in deep waters.

Because high carbon dioxide uptake was measured simultaneously with no net oxygen production, the peak of $\mathrm{BChl} a$, and the lowest PQ ratio in the suboxic waters of central sector, AnAnP bacteria appear to be the main photosynthetic players within this area, benefiting from suboxia and low light intensity in the bottom water in fall, as is usually observed in meromictic lakes [49]. The presence of purple sulfur bacteria only in the bottom waters of site 33 supports this hypothesis. These bacteria (PSBChromatiaceae-like) are found in other similar systems [7, 10, 21, 24], and it is known that Chromatiaceae-like cells have long doubling time, from 1.5 to up to 238 days, depending on the abiotic conditions [21]. In Conceição Lagoon, PSB contributed with only $1.2 \%$ of the total bacterial density in May, while their biomass accounted for $12.2 \%$ of total bacterial community biomass (average diameter $=5 \mu \mathrm{m}$ and biovolume $=20 \mu \mathrm{m}^{3}$ ). Consequently, larger and active bacterial cells may be an important carbon link within the microbial food web. However, high light $\mathrm{CO}_{2}$ fixation and low OP were also measured at surface oxic waters of stations 6 and 12 at the south during the same period (Fig. 5). This observation raised two important questions: are the bacterial communities of oxic waters of the southern sector and suboxic waters of the central sector similar and how would AnAnP bacteria survive under oxic conditions?

The cluster analysis of DGGE patterns obtained from the amplification of $16 \mathrm{~S}$ genes of bacterial communities of one representative site per sector showed that the bacterial community structure of suboxic bottom waters of site 33 and oxic surface waters of site 12 in fall showed $65 \%$ similarity (Fig. 6). A $60 \%$ similarity between the anoxic and oxic waters was also reported in the Chesapeake Bay during the early development of anoxia in the summer [12], which could be the case in the Conceição Lagoon, since suboxic waters developed only 20 days before our samples were collected (Fontes and Abreu, in preparation). Regarding the second question, it is likely that the high concentration of larger particles in the southern sector [31] can provide adequate conditions for the activity of AnAnP bacteria attached to or embedded in the particles, which can explain the uncoupling of $\mathrm{CO}_{2}$ fixation and $\mathrm{OP}$ and its high similarity with the bacterial community of suboxic waters. Microhabitats with low oxygen/light are known to be formed inside suspended particles $(>500 \mu \mathrm{m})$ [50], leading to the development of a $\mathrm{H}_{2} \mathrm{~S}_{/} \mathrm{SO}_{4}{ }^{-}$gradient within the particle. In other coastal systems like the Delaware and Chesapeake estuaries and Lapalme Lagoon, AAnP bacteria were preferentially attached to particles $[37,60,61]$, which might also be the case for their anaerobic counterpart, the AnAnP bacteria, in Conceição Lagoon.

To estimate the contribution of $\mathrm{BChl} a$-driven anoxygenic bacterial photosynthesis to energy production in a system, the $\mathrm{BChl} a / \mathrm{Chl} a$ ratio is used [22] due to the fact that AAnP bacteria display a similar light utilization efficiency per chromophore unit as oxygenic photoautotrophs, making the rates of photosynthesis possibly related to the concentrations of $\mathrm{Chl} a$ and $\mathrm{BChl}$ a [36]. The average $\mathrm{BChl} a / \mathrm{Chl} a$ ratios in Conceição Lagoon were 0.15 in summer and 0.27 in fall. These values were much higher than the average ratios of 0.008 and 0.01 estimated by Goericke [22] and Cottrell et al. [11], respectively, but closer to the assumption made by Kolber et al. [36] that a global $\mathrm{BChl} a / \mathrm{Chl} a$ ratio would vary between 0.05 and 0.10 . However, it is important to point out that these mentioned ratios were calculated for oxic waters, and thus, they are most likely to be based on the BChl $a$ of AAnP bacteria. On the other hand, our ratios were based on the $\mathrm{BChl} a$ of both groups of anoxygenic bacteria (AAnP and AnAnP bacteria-aerobes and anaerobes), which may explain the higher contribution of BChl $a$-containing bacteria to total photosynthesis found in our study.

The results of this study suggest a high contribution of anaerobic anoxygenic phototrophic bacteria to total pelagic primary production (up to $45 \%$ of the photosynthetic electron transfer in the suboxic waters, i.e., dead zones), incorporating $\mathrm{CO}_{2}$ into organic carbon. The similar $\mathrm{BChl}$ $a / \mathrm{Chl} a$ ratios and decoupled $\mathrm{CO}_{2}$ fixation and $\mathrm{O}_{2}$ production rates found in the oxic waters of station 12 (southern sector, more turbid area) and the suboxic waters of station 33 (central sector, clear area) support the high similarity between bacterial communities of suboxic and oxic turbid waters, reinforcing the probability of microhabitat formation in surface waters. Primary production of anaerobic anoxygenic phototrophic bacteria should be considered in future studies of carbon fluxes because this 
is an important and general process occurring in many stratified shallow aquatic systems (lakes, lagoons, estuaries, and bays) throughout the world.

Acknowledgments We are grateful to A. Shu, T. G. Rosa, and A. da Silva for sampling assistance, T. Gandra for map editing assistance, and Dr. B. Spoganicz for sharing his laboratory and the help of his undergraduate students to process water samples. We wish to thank L. Yu for aid with the DGGE. Part of the research was funded by grant OCE-0550547 from the US National Science Foundation to MTS and from CAPES to PCA and MLSF.

\section{References}

1. Abreu PC, Biddanda BB, Odebrecht C (1992) Bacterial dynamics of the Patos Lagoon estuary, southern Brazil (32-degrees-S, 52degrees-W) - relationship with phytoplankton and suspended material. Estuar Coast Shelf Sci 35:621-635

2. Abreu PC, Odebrecht C, González A (1994) Particulate and dissolved phytoplankton production of the Patos Lagoon estuary, southern Brazil: comparison of methods and influencing factors. J Plankton Res 16:737-753

3. Assumpção DTG, Toledo APP, D’Aquino VA (1981) Levantamento ecológico da Lagoa da Conceição (Florianópolis, Santa Catarina) I: Caracterização-parâmetros ambientais. Ciênc Cult 33:1096-1101

4. Bauer CE, Buggy JJ, Mosley C (1993) Control of photosystem genes in Rhodobacter capsulatus. Trends Genet 9:56-60

5. Bergondo DL, Kester DR, Stoffel HE, Woods WL (2005) Timeseries observations during the low sub-surface oxygen events in Narragansett Bay during summer 2001. Mar Chem 97:90-103

6. Brewer PG, Peltzer ET (2009) Limits to marine life. Science 324:347-348

7. Camacho A, Vicente E, Miracle MR (2000) Spatio-temporal distribution and growth dynamics of phototrophic sulfur bacteria populations in the sulfide-rich Lake Arcas. Aquat Sci 62:334-349

8. Casamayor EO, Garcia-Cantizano J, Pedrós-Alió C (2008) Carbon dioxide fixation in the dark by photosynthetic bacteria in sulfiderich stratified lakes with oxic-anoxic interfaces. Limnol Oceanogr 53:1193-1203

9. Casamayor EO, Garcia-Cantizano J, Mas J, Pedrós-Alió C (2001) Primary production in estuarine oxic/anoxic interfaces: contribution of microbial dark CO2 fixation in the Ebro River Salt Wedge Estuary. Mar Ecol Prog Ser 215:49-56

10. Cohen Y, Krumbein WE, Shilo M (1977) Solar Lake (Sinai) 2. Distribution of photosynthetic microorganisms and primary production. Limnol Oceanogr 22:609-620

11. Cottrell MT, Mannino A, Kirchman DL (2006) Aerobic anoxygenic phototrophic bacteria in the Mid-Atlantic Bight and the North Pacific Gyre. Appl Environ Microbiol 72:557-564

12. Crump BC, Peranteau C, Beckingham B, Cornwell JC (2007) Respiratory succession and community succession of bacterioplankton in seasonally anoxic estuarine waters. Appl Environ Microbiol 73:6802-6810

13. Diaz RJ (2001) Overview of hypoxia around the world. J Environ Qual 30:275-281

14. Diaz RJ, Rosenberg R (2008) Spreading dead zones and consequences for marine ecosystems. Science 321:926-929

15. Folt CL, Wevers MJ, Yoder-Williams MP, Howmiller RP (1989) Field study comparing growth and viability of a population of phototrophic bacteria. Appl Environ Microbiol 55:78-85

16. Fonseca AL (2004) Variação sazonal e espacial das características hidroquímicas, dos fluxos de nutrientes e do metabolismo na interface água-sedimento da Lagoa da Conceição (SC, Brasil). Universidade Federal de São Paulo, São Paulo, p 180

17. Fonseca AL, Braga ES (2006) Temporal dynamic of the dissolved nutrients and the eutrophization processes in a southern Brazilian coastal lagoon, Conceição Lagoon. J Coast Res SI 39:1229-1233

18. Fonseca AL, Braga E, Eichler B (2002) Distribuição espacial dos nutrientes inorgânicos dissolvidos e da biomassa fitoplanctônica no sistema pelágico da Lagoa da Conceição, Santa Catarina, Brasil (Setembro, 2000). Atlântica 24:69-83

19. Fontes MLS (2004) Breve estudo espaço-temporal e de impacto do feriado de Carnaval e de Corpus Christi sobre variáveis ambientais nas águas da Lagoa da Conceição, Florianópolis. Universidade Federal de Santa Catarina, Florianópolis, p 133

20. Fontes MLS, Abreu PA (2009) Spatiotemporal variation of bacterial assemblages in a shallow subtropical coastal lagoon in southern Brazil. Microb Ecol 58:140-152

21. Garcia-Cantizano J, Casamayor EO, Gasol JM, Guerrero R, Pedrós-Alió C (2005) Partitioning of CO2 incorporation among planktonic microbial guilds and estimation of in situ specific growth rates. Microb Ecol 50:230-241

22. Goericke R (2002) Bacteriochlorophyll a in the ocean: is anoxygenic bacterial photosynthesis important? Limnol Oceanogr 47:290-295

23. Grasshoff K, Ehrhardt M, Kremling K (1999) Methods of seawater analysis. Wiley-VCH, Weinhein

24. Guerrero R, Montesinos E, Pedros-Alio C, Esteve I, Mas J, Gemerden HV, Hofman PAG, Bakker JF (1985) Phototrophic sulfur bacteria in two Spanish lakes: vertical distribution and limiting factors. Limnol Oceanogr 30:919-931

25. Hammer O, Harper DAT, Ryan PD (2001) Paleontological statistics software package for education and data analysis. Paleontol Electon 4:9-17

26. Helly JJ, Levin LA (2004) Global distribution of naturally occurring marine hypoxia on continental margins. Deep-Sea Res Part 1 Oceanogr Res Pap 51:1159-1168

27. Hobbie JE, Daley RJ, Jasper S (1977) Use of nuclepore filters for counting bacteria by fluorescence microscopy. Appl Environ Microbiol 33:1225-1228

28. Irwin B (1991) Coulometric measurement of primary production, with comparison against dissolved oxygen and $14 \mathrm{C}$ methods in a seasonal study. Mar Ecol Prog Ser 71:97-102

29. Jones JG (1979) A guide to methods for estimating microbial numbers and biomass in freshwater. Scientific, Ambleside

30. Kjerfve B (1986) Comparative oceanography of coastal lagoons. In: Wolf D (ed) Estuarine variability. Academic, New York, pp 63-81

31. Knoppers B, Opitz S, Souza M, Miguez C (1984) The spatial distribution of particulate organic matter and some physical and chemical water properties in Conceição Lagoon, Santa Catarina, Brazil (July 19, 1982). Braz Arch Biol Technol 27:59-77

32. Koblizek M, Ston-Egiert J, Sagan S, Kolber ZS (2005) Diel changes in bacteriochlorophyll a concentration suggest rapid bacterioplankton cycling in the Baltic Sea. FEMS Microbiol Ecol 51:353-361

33. Koblizek M, Masin M, Ras J, Poulton AJ, Prasil O (2007) Rapid growth rates of aerobic anoxygenic phototrophs in the ocean. Environ Microbiol 9:2401-2406

34. Koblizek M, Shih JD, Breitbart SI, Ratcliffe EC, Kolber ZS, Hunter CN, Niederman RA (2005) Sequential assembly of photosynthetic units in Rhodobacter sphaeroides as revealed by fast repetition rate analysis of variable bacteriochlorophyll a fluorescence. Biochim Biophys Acta Bioenerg 1706:220-231

35. Kolber ZS, Van Dover CL, Niederman RA, Falkowski PG (2000) Bacterial photosynthesis in surface waters of the open ocean. Nature 407:177-179 
36. Kolber ZS, Plumley FG, Lang AS, Beatty JT, Blankenship RE, VanDover CL, Vetriani C, Koblizek M, Rathgeber C, Falkowski PG (2001) Contribution of aerobic photoheterotrophic bacteria to the carbon cycle in the ocean. Science 292:2492-2495

37. Lami R, Cuperová Z, Ras J, Lebaron P, Koblizek M (2009) Distribution of free-living and particle-attached aerobic anoxygenic phototrophic bacteria in marine environments. Aquat Microb Ecol 55:31-38

38. Lin H-J, Hung J-J, Shao K-T, Kuo F (2001) Trophic functioning and nutrient flux in a highly productive tropical lagoon. Oecologia 129:395-406

39. Massana R, Gasol JM, Bjornsen PK, Blackburn N, Hagstrom A, Hietanen S, Hygum BH, Kuparinen J, PedrosAlio C (1997) Measurement of bacterial size via image analysis of epifluorescence preparations: description of an inexpensive system and solutions to some of the most common problems. Sci Mar 61:397-407

40. Medina-Gomez I, Herrera-Silveira JA (2006) Primary production dynamics in a pristine groundwater influenced coastal lagoon of the Yucatan Peninsula. Cont Shelf Res 26:971-986

41. Montes-Hugo MA, Alvarez-Borrego S, Gaxiola-Castro G (2004) Annual phytoplankton production in a coastal lagoon of the southern California Current System. Mar Ecol Prog Ser 277:5160

42. Muehe D, Caruso F Jr (1989) Batimetria e algumas considerações sobre a evolução geológica da Lagoa da Conceição, Ilha de Santa Catarina. Geosul 49:32-44

43. Muyzer G, Dewaal EC, Uitterlinden AG (1993) Profiling of complex microbial-populations by denaturating gradient gelelectrophoresis analysis of polymerase chain reaction-amplified genes-coding for $16 \mathrm{~S}$ ribosomal-RNA. Appl Environ Microbiol 59:695-700

44. Nielsen GE, Bresta A-M (1984) Guidelines for the measurement of phytoplankton primary production. Baltic Mar Biol 1:1-23

45. Nixon SW (1995) Coastal marine eutrophication: a definition, social causes, and future concerns. Ophelia 41:199-219

46. Norland S (1993) The relationship between biomass and volume of bacteria. In: Kemp PF, Sherr BF, Sherr EB, Cole JJ (eds) Handbook of methods in aquatic microbial ecology. Lewis, Boca Raton, pp 303-307

47. Odebrecht C, Caruso F (1987) Hidrografia e matéria particulada em suspensão na Lagoa da Conceição, Ilha de Santa Catarina, SC, Brasil. Atlântica 9:83-104
48. Overmann J, Fischer U, Pfennig N (1992) A new purple sulfur bacterium from saline littoral sediments, Thiorhodovibriowinogradskyi gen-nov and sp-nov. Arch Microbiol 157:329-335

49. Parkin TB, Brock TD (1980) Photosynthetic bacterial production in lakes: the effects of light intensity. Limnol Oceanogr 25:711-718

50. Ploug H, Kuhl M, Buchholz-Cleven B, Jorgensen BB (1997) Anoxic aggregates - an ephemeral phenomenon in the pelagic environment? Aquat Microb Ecol 13:285-294

51. Schindler DW, Schmidt RV, Reid RA (1972) Acidification and bubbling as an alternative to filtration in determining phytoplankton production by the ${ }^{14} \mathrm{C}$ method. J Fish Res 29:1627-1631

52. Sierra de Ledo B, Soriano-Sierra E (1994) Atributos e processos condicionantes da hidrodinâmica na Lagoa da Conceição, Ilha de Santa Catarina, Brasil. ACIESP 2:113-121

53. Strickland J, Parsons T (1972) A practical handbook of seawater analysis, 2nd edn. Fisheries Research Board of Canada, Ottawa

54. Suzuki MT, Christina MP, Francisco PC, Edward FD (2001) Quantitative mapping of bacterioplankton populations in seawater: field tests across an upwelling plume in Monterey Bay. Aquat Microb Ecol 24:117-127

55. Taddei D, Cuet P, Frouin P, Esbelin C, Clavier J (2008) Low community photosynthetic quotient in coral reef sediments. CR Biol 331:668-677

56. Takahashi M, Ichimura SE (1970) Photosynthetic properties and growth of photosynthetic sulfur bacteria in lakes. Limnol Oceanogr 15:924-944

57. Underwood AL (1997) Experiments in ecology: their logical design and interpretation using analysis of variance. Cambridge University, Sidney

58. Utermohl H (1958) Zur Vervollkommnung der quantitativen Phytoplankton Methodik. Mitt Int Verein Theor Angewandte Limnol 9:1-38

59. Vaquer-Sunyer R, Duarte CM (2008) Thresholds of hypoxia for marine biodiversity. Proc Natl Acad Sci USA 105:15452-15457

60. Waidner LA, Kirchman DL (2007) Aerobic anoxygenic phototrophic bacteria attached to particles in turbid waters of the Delaware and Chesapeake estuaries. Appl Environ Microbiol 73:3936-3944

61. Waidner LA, Kirchman DL (2008) Diversity and distribution of ecotypes of the aerobic anoxygenic phototrophy gene pufM in the Delaware estuary. Appl Environ Microbiol 74:4012-4021

62. Yurkov VV, Beatty JT (1998) Aerobic anoxygenic phototrophic bacteria. Microbiol Mol Biol Rev 62:695-724

63. Zar JH (1999) Biostatistical analysis. Prentice-Hall, Englewood Cliffs 